\title{
Correction to: Healthcare expenditure and carbon footprint in the USA: evidence from hidden cointegration approach
}

\section{Murat Gündüz ${ }^{1}$ [D}

Published online: 21 October 2020

c) Springer-Verlag GmbH Germany, part of Springer Nature 2020

\section{Correction to: \\ The European Journal of Health Economics (2020) 21:801-811 \\ https://doi.org/10.1007/s10198-020-01174-z}

The author would like to correct the errors in the publication of the original article. The correct details are given below.

(a). Page 807: "Crouching error correction models were obtained through Stepwise regression method by using maximum10 lagged variables" should be changes to: "Crouching error correction models were obtained through Stepwise regression method by using maximum 10 lagged variables [35].
The original article can be found online at https://doi.org/10.1007/ s10198-020-01174-z.

\section{Murat Gündüz}

murat.gunduz@usak.edu.tr

1 Faculty of Economics and Administrative Sciences, Department of Econometrics, Usak University, Usak, Turkey

\section{Reference}

35. Mert, M., Çağlar, A.E.: Eviews ve Gauss Uygulamalı Zaman Serileri Analizi [Eviews and Gauss Applied Time Series Analysis]. Detay Yayınc1lık, Ankara (2019). ISBN: 978-605-254-126-5

Publisher's Note Springer Nature remains neutral with regard to jurisdictional claims in published maps and institutional affiliations. 